\section{SOI: 1.1 /TAS DOI: 10.15863 /TAS International Scientific Journal Theoretical \& Applied Science}

p-ISSN: 2308-4944 (print)

e-ISSN: 2409-0085 (online)

Year: 2016

Issue:

Volume: 33

Published: $30.01 .2016 \quad$ http://T-Science.org
Gennady Evgenievich Markelov

Candidate of Engineering Sciences, associate professor,

Bauman Moscow State Technical University, Moscow, Russia markelov@bmstu.ru

SECTION 21. Pedagogy. Psychology. Innovations in the field of education.

\title{
TEACHING THE BASICS OF MATHEMATICAL MODELING. PART 2
}

Abstract: The article outlines some important aspects related to teaching the basics of mathematical modeling. It describes a unified approach to building mathematical models. Guidelines for using information and communication technologies and an individual approach to teaching are provided. The article also looks at details of organizing teaching sessions. The application of such aspects and guidelines enhances the quality of graduates' training and increases their competitiveness.

Key words: mathematical modeling, unified approach to the construction of models, information and communication technologies, individual approach, organization of training, quality training, competitiveness.

Language: English

Citation: Markelov GE (2016) TEACHING THE BASICS OF MATHEMATICAL MODELING. PART 2.

ISJ Theoretical \& Applied Science, 01 (33): 72-74

Soi: http://s-o-i.org/1.1/TAS-01-33-15 Doi: crossef http://dx.doi.org/10.15863/TAS.2016.01.33.15

\section{Introduction}

Today, mathematical modeling is extensively used in machine and instrumentation engineering. In this context, it is critical to teach a discipline focused on studying advanced methods of building mathematical models, ways of quantitative and qualitative analysis of mathematical models, methods of rational application of mathematical modeling to machine and instrumentation engineering.

The purpose of this article is to outline some important aspects related to the basics of mathematical modeling. The application of such aspects and guidelines improves students' training for their future employment in the machine and instrumentation engineering industries and enhances their competitiveness.

The article takes into account the guidelines formulated in $[1 ; 2]$.

\section{Unified Approach to the Construction of Models}

The potential of mathematical modeling that are described in detail in the literature (for example, [36]) are often used inefficiently. The reason for this is that the mathematical model does not have the desired properties.

Developing a mathematical model with required properties in terms of a specific research problem involves compliance with the requirements for such a mathematical model. Such requirements are inconsistent and may be met in practice only on a reasonable compromise basis.

Generally, building such models relies on the rules and recommendations arising from the accumulated experience in developing mathematical models. The mathematical modeling principles are of special interest. For example, [7] defines the principles whose reasonable use in aggregate allows us to implement a consistent approach to building mathematical models with required properties in terms of a specific research problem. Examples of building such models are provided in [8;9].

Experience shows that a unified approach to building mathematical models is promising and deserves appropriate attention.

3. Information and Communication Technologies

Teaching the basics of mathematical modeling involves using the following electronic materials:

$\checkmark$ theoretical materials, such as textbooks, manuals, and lecture notes;

$\checkmark \quad$ practice materials, such as exercise books and workbooks;

$\checkmark$ methodical materials, such as study guides;

$\checkmark$ reference books, such as terminological dictionaries and reference guides;

$\checkmark$ any other necessary materials, such as multimedia presentations and software. 
Students should be provided with e-learning tools, self-testing opportunities and online consultations.

Studying a discipline related to the basics of mathematical modeling involves learning information loaded with various concepts and terms related to different mathematical disciplines in combination with terminology and extensive information from science and engineering disciplines. This creates learning challenges to be met with an electronic information reference system. Features of development of such a system are described in [10].

One good example of using information and communication technologies is the Basics of Mathematical Modeling, a multimedia course developed by the author at the Department of Applied Mathematics of the Bauman Moscow State Technical University. The lecture series was delivered in specially equipped classrooms making it possible to view multimedia presentations, use online resources on the equipment connected to wireless networks.

Introduction of information and communication technologies into the learning process enhances training effectiveness; however, it takes considerable and time-consuming efforts requiring extensive knowledge as well as the use of advanced hardware and software.

Extensive use of sophisticated information and communication technologies in the training process fosters further development of information and educational environment, which makes successful training possible.

\section{Organization of Teaching}

The curriculum of a discipline teaching the basics of mathematical modeling involves lectures as well as practical training. Lectures teach methods of building mathematical models with the desired properties, ways of quantitative and qualitative analysis of mathematical models, and methods of practical interpretation of the results of mathematical modeling. Practical training sessions teach students to develop mathematical models, select the appropriate analytical tools for the designed mathematical models, and process and present the results of mathematical modeling.

Knowledge and skills are reinforced by individual homework. Such homework is related to building a hierarchy of mathematical models and analysis of the models, which allows students to make meaningful conclusions.

Organization of training classes and a system of monitoring the teaching results should enable fair assessment of teaching outcomes, motivate students to work systematically, enhance learning competition, and develop performance self-control ability.

\section{Individual Approach}

Individual approach to training requires consistent monitoring of each student's performance throughout the semester, fair assessment of knowledge and skills gained, while taking into account the student's personal qualities and individual abilities. This will enable taking timely measures aimed at improving the learning performance, development of personal qualities and individual abilities of students. For example, students may be assisted in adapting to the training process, informed selection of a learning trajectory, and teaching may be customized for each student by offering additional materials for self-study.

An individual training approach enhances the effectiveness of learning, encourages the development of personal qualities and individual abilities; however, such individual approach involves provision of the relevant learning aids and development of student incentive schemes.

\section{Conclusion}

Thus, the article outlines some important aspects related to teaching the basics of mathematical modeling and draws the following conclusions:

$\checkmark$ attention should be given to a unified approach to building mathematical models with required properties in terms of a specific research problem;

$\checkmark \quad$ it necessitates active introduction of advanced information and communication technologies into the teaching process and further development of the information and learning environment;

$\checkmark$ compliance with the requirements for a discipline teaching the basics of mathematical modeling involves the appropriate organization of the teaching classes and fair assessment of learning outcomes;

$\checkmark \quad$ the considered properties of the individual approach enhance learning effectiveness and development of personal qualities and individual abilities of students.

The above-mentioned aspects and guidelines improve the students' quality of learning for their future employment in the rapidly changing world, total interdependency and global competition. 


\begin{tabular}{l|lrl|l|ll} 
& ISRA (India) & $=\mathbf{1 . 3 4 4}$ & SIS (USA) & $=\mathbf{0 . 9 1 2}$ & ICV (Poland) & $=\mathbf{6 . 6 3 0}$ \\
Impact Factor: & ISI (Dubai, UAE) $=\mathbf{0 . 8 2 9}$ & PUHIL (Russia) $=\mathbf{0 . 1 7 9}$ & PIF (India) & $=\mathbf{1 . 9 4 0}$ \\
& GIF (Australia) & $\mathbf{0 . 5 6 4}$ & ESJI (KZ) & $=\mathbf{1 . 0 4 2}$ & & \\
\hline JIF & $=\mathbf{1 . 5 0 0}$ & SJIF (Morocco) $=\mathbf{2 . 0 3 1}$ & & \\
\hline
\end{tabular}

\section{References:}

1. Markelov GE (2015) Content of the Course «Fundamentals of Mathematical Modeling». ISJ Theoretical \& Applied Science 05 (25): 5961. Soi: http://s-o-i.org/1.1/TAS*05(25)12 Doi: http://dx.doi.org/10.15863/TAS.2015.05.25.12

2. Markelov GE (2015) Particular Aspects of Teaching the Fundamentals of Mathematical Modeling. ISJ Theoretical \& Applied Science 05 (25): 69-72. Soi: http://s-oi.org/1.1/TAS*05(25)14 Doi: http://dx.doi.org/10.15863/TAS.2015.05.25.14

3. Dym CL (2004) Principles of Mathematical Modeling. Elsevier Academic Press.

4. Myshkis AD (2014) Elements of the Theory of Mathematical Models [in Russian]. LENAND, Moscow.

5. Samarskii AA, Mikhailov AP (2002) Principles of Mathematical Modeling: Ideas, Methods, Examples. Taylor \& Francis, London.

6. Zarubin VS (2010) Mathematical Modeling in Engineering [in Russian]. Izd-vo MGTU im. N.E. Baumana, Moscow.
7. Markelov GE (2006) Principles to Construct Mathematical Models. Proc. of the Int. Conf. "Tikhonov and Contemporary Mathematics: Mathematical Modeling”, Izd. otd. fak. VMiK MGU im. M.V. Lomonosova, Moscow, pp. $128-129$.

8. Markelov GE (2012) Peculiarities of Construction of Mathematical Models. Inzhenernyi zhurnal: nauka i innovatsii, No. 4, Available:

http://engjournal.ru/catalog/mathmodel/hidden/ 150.html (Accessed: 03.11.2012).

9. Markelov GE (2015) Constructing a Working Mathematical Model. ISJ Theoretical \& Applied Science 08 (28): 44-46. Soi: http://s-oi.org/1.1/TAS-08-28-6 Doi: http://dx.doi.org/10.15863/TAS.2015.08.28.6

10. Zarubin VS, Markelov GE (2006) Features of the development of electronic informationreference system on mathematics for technical colleges. Uchenye zapiski IIO RAO, IIO RAO, Moscow, Iss. 19, pp. 196-197. 